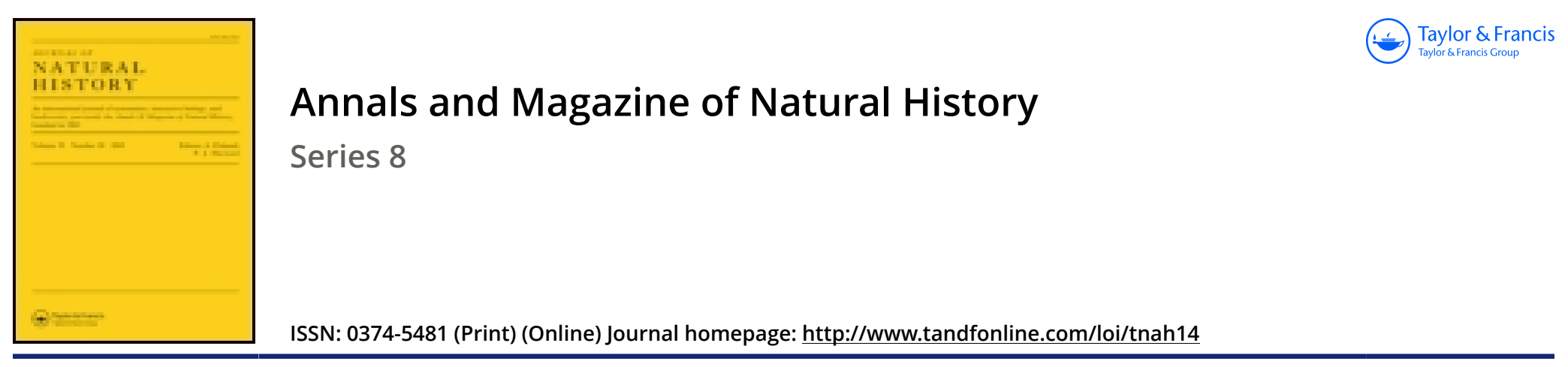

\title{
LIV.-New species of the genus Platampos, reitt. [= Spithobates, champ.] (Coleoptera), from Tropical South America
}

\section{G. C. Champion F.Z.S.}

To cite this article: G. C. Champion F.Z.S. (1916) LIV.-New species of the genus Platampos, reitt. [= Spithobates, champ.] (Coleoptera), from Tropical South America, Annals and Magazine of Natural History, 17:102, 470-474, DOI: 10.1080/00222931608693812

To link to this article: http://dx.doi.org/10.1080/00222931608693812

曲 Published online: 11 Sep 2009.

Submit your article to this journal $\pi$

Џll Article views: 3

Q View related articles $\sqsubset$ 
and the Asiatic locality published with the description is certainly wrong.

Bombus mexicanus, Cress. $(1878)=B$. unifasciatus, Smith (1879). The type $\Varangle$ of $B$. unifasciatus is marked with the word "type" by Smith himself, and the other specimens are unmistakably the types of the other castes.

Bombus diligens, Smith $(1861)=B$. brachycephalus, Handlirsch (1888).

LIV. - New Species of the Genus Platamops, Reitt. [=Spithobates, Champ.] (Coleoptera), from Tropical Soudh America. By G. C. Champlon, F.Z.S.

The genus Platamops, including two species from Colombia, was described by Reitter * (1878) as a Cncujid, and said to have simple, 5-jointed tarsi, with a feebly lobel third joint. There can be no doubt, however, from the other characters given, that his definition of the tarsi was inaccurate (possibly he did not examine the pnsterior pair, or they were nissing in his types), and that Platamops is synonymous with the Pythid-genus Spithobates, Champ. $+(1889)$, also based upon two Tropical American forms. The four species now added, one from Colombia and three from Brazil, are all contained in the British Mnseum. These insects have the tarsi 5-, 5-, 4.-jointed in both sexes, and the ante-penultimate joint a little stouter than the minnte penultimate one; the anterior coxal cavities open behind; the prothorax with four or five setigerons tubencles along the lateral margin; and the elytra clothed with intermixed long, erect, tactile sete and decumbent hairs. The general facies is very like that of the Cucujid genera Telephanus and Cryptamorpha, and this doubtless deceived the Austrian author, who comnared Platamops with Platamus, Fr., and Parabrontes, Redt., wherens the affivity with the Pythid-genus Salpingus, Gyll. (Sphariestes, Steph.), is obvious. The species here described have six of the outer antemual joints widened, as in the P. (Syithobates) setosus, Champ., from Chiriqui, the three terminal joints only being thickened in the Central American

* Verh. zuol.-bot. Ges. Wien, xxvii. p. 177 (187\%, issued in 1878).

F Biol. Centr.-Am., Coleopt. iv. 2. p. 104 (1889). 
$P$. (Spithobutes) maculatus, Champ. The types of $P$. decoratus and $P$. vittatus, Reitt., are, I believe, in the Oberthür cullection at Rennes. The eight species may be tabulated thus :-

Antenna widened from fifth joint.

Eyes larger; elytra inmaculate .... setosus, ('hamp. Panama.]

Eyes smaller; elytra maculate.

Prothorax smooth at base; elytra bimaculate ................

Prothorax closely punctate to base. Elytra strongly attenuate posteriorly, fuseo-bicruciate ....

Flytra less attenuate posteriorly.

Elytra transwersely bifasciate, irregularly punctate $\ldots$...

Elytra obliquely bifasciate, striato-punctate $\ldots \ldots \ldots$

Elytra quadrimaculate .......

Elytra vittate ..............

Antenne widened from ninth joint;
elytra spotted ...............

binotatus, sp. n. [Colombia.]

telephanoides, sp. n. [Brazil.]

decoratus, sp. n. [Colombia.]

obliquus, sp. n. [Brazil.]

4-signatus, sp. n. [Brazil.]

vittatus, Reitt. [Colombia.]

maculatus, Champ. [Central

\section{Platamops binotatus, sp. n.}

Elongate, attenuate posteriorly, shining; nigro-piceous, the head in front, the basal joints and tip of the antennæ, the Hanks of the prothorax, and a large patch on each elytron bejow the humeri, rufous or ferruginous, the tarsi testaceous, the femora and tibia darker; very sparsely clothed with decumbent yellow hairs intermixed with very long, erect, scattered setre. Head rugosely punctate on each side of the smooth median space, the eyes rather small, prominent; antemme long, joints 5-10 subequal, longer than broad. Prothorax convex, oblong-cordate, strongly constricted and transversely sulcate before the base; sparsely, coarsely, separately punclate on each side of the rather broad smooth median space, the constricted basal portion almost impunctate, the five setigerous marginal tubercles small. Elytra moderately elongate, broad, gradually widened to the middle and rapidly nariowed thence to the apex, the transverse postbasal depression deep; sparsely, rather coarsely punctate, the punctures becoming very small from the middle onwards, and showing a faint trace of a linear arangement on the disc, the postmedian sutural depression rather deep, the interstices smooth, flat on the disc, uneven tuwards the sides and apex. Intermediate and posterior tarsi very elongate, much longer than the anterior pair. 
Length $5 \mathrm{~mm}$. ( $\delta$ ?)

Hab. Colombia, Santa Fé de Bogota (Mus. Brit.).

One specimen, acquired by the Museum in 1871. This insect is labelled" "heteromère," showing that its systematic position was then recognized. The comparatively smooth prothorax, long antenne, and rufo-bimaculate elytra are characteristic. A Palæarctic Salpingus (Sphcriestes) is similarly coloured.

\section{Platamops telephanoides, sp. n.}

Elongate, narrow, attenuate posteriorly, shining; ferruginous, the eyes black, the legs and elytra testaceous, the latter with a large, common, subtriangular, scutellar patch connected along the suture with a broader saddle-shaped mark, a common oval patch towards the apex, and an indeterminate space along the sides (extending from just below the humeri to about one-third from the apex, and usually obliquely coalescent posteriorly with the saddle-shaped mark) piceous or nigro-piceous, the under surface and antennæ piceous or obscure ferruginous, the latter with the basal joints and extreme tip testaceous; sparsely clothed with decumbent yellow hairs intermixed with very long, erect, darker setæ. Head rugosely punctate, smooth down the middle, the eyes very prominent ; antennæ moderately long, joints 5-10 very gradually decreasing in length, 7-10 triangular, 11 ovate. Prothorax oblong-cordate, constricted and transversely depressed before the base, longitudinally rugose, except along the smooth median line, the five setigerous marginal tubercles well dereloped. Elytra long, rapidly narrowed from the middle, narrow at the tip; obliquely depressed on the disc below the base, rather coarsely striato-punctate, the punctures becoming very minute on the apical declivity, the interstices flat and almost smooth.

Length $4 \frac{4}{5}-5 \mathrm{~mm}$. ( $\delta$ \% .)

$H a b$. Brazil, Rio de Janeiro (Fry).

Four specimens. More elongate than the allied forms, and with the elytral markings very similar to those of various species of the Cucujid genera Telephanus and Oryptamorpha.

\section{Platamops obliquus, sp. n.}

Moderately elongate, shining; nigro-piceous or piceous, the head and prothorax sometimes wholly or in part ferruginous, the basal joints and tip of the antennæ, the knees and tarsi, and various markings on the elytra testaceous 
or ochraceous; the elytral markings consisting of two fasciæ on the disc, neither reaching the suture-the antemedian one transverse and extending downward on the outer part of the dise (in one specimen divided into two spots), the postmedian one oblique and extending outward to near the margin,- - a spot on the shoulder (sometimes extending across the base), and a small apical patch; sparsely clothed with decumbent yellow hairs intermixed with numerous, very long, erect, dark setæ. Head rugosely punctate on each side of the smooth median space; antennæ with joints 5-10 subtriangular, slightly decreasing in length. Prothorax oblongcordate, narrower in $q$, constricted and tîansversely depressed before the base, longitudinally rugose, except along the smooth median line, the setigerous marginal tubercles well developed, Elytra moderately long, subparallel in their basal half; interruptedly striato-punctate, the punctures becoming very tine towards the apex, the transverse postbasal depression deep, the interstices almost smooth, flat on the disc, uneven towards the sides. Penis-sheath of $z$ curved and acuminate at the tip, two long filamentary processes projecting from it beneath, each process dilated at the apex and bearing a conspicuous seta.

Length $3 \frac{1}{3}-4 \frac{1}{5} \mathrm{~mm}$. ( $\left.\sigma^{*} q.\right)$

Hal. Brazil, Rio de Janeiro $(F \cdot y)$.

Seven specimens, one somewhat immature. This species seems to be very nearly related to, and a little smaller than, $P$. decoratus, Reitt, from La Luzera, Colombia; but the elytra in the latter are said to be irregularly punctate, and to have two transverse fasciæ, the suture, base, and apex ferruginous. In the Brazilian insect the dark portions of the elytra are condensed into a narrow sutural stripe, a postbasal fascia, a common saddle-shaped mark at the middle, and a large, common, oval, subapical patch. The æedeagus is partly extruded in two of the males betore me.

\section{Platamops quadrisignatus, sp. n.}

Moderately elongate, rather convex, shining; piceous or obscure ferruginous, the basal joints and tip of the antennæ, the tarsi, and a large humeral patch on each elytron and an indeterminate patch of variable extent on the disc towards the apex (not reaching the suture), testaceous or rufescent; sparsely clothed with decumbent yellow hairs intermixed with numerous, very long, erect, darker setæ. Head rugosely punctate on each side of the smooth median space; antennæ rather short, joints 5-10 subequal in length, 6-10 subtriangular. Prothorax oblong-cordate, longitudinally rugose 
on each side of the smooth median line, constricted and transversely depressed before the base, the tive setigcrous marginal tubercles well developed. Elytra moderately lone, subparallel in their basal half and arcuately narrowed thence to the apex, the post-basal depression deep ; with in terrupted rows of scattered punctures, which become very fine towards the apex, the scutellar region sometimes with additional scattered punctures, the interstices smooth and flat.

Length $3 \frac{1}{2}-4 \mathrm{~mm}$. ( $\delta q$. )

Hab. Brazrl, Rio de Janeiro, Pernambuco (Fry).

Described from three specinens. A tourth example (one of the two from Peinambuco), somewhat inmature, with a broader head and prothorax, larger eyes, and more closely punctate elytra, seems to belong to the same species. The elytral markings are not unilike those of the variable $P$. maculatzs, Champ., from Central America, which has the antennal joi:sts 9 and 10 longer and stouter than those preceding, and the elytra regularly striato-punctate. $P$. vittalus, Reitt., is said to havo the elytra ferruginous, with the snture and sides broadly nigro-piceous, and it cannot therefore be conspecific with the present species.

\section{LV.-Some new Lepidoptera from Siam and Africa. By Lord Rothschild, F.R.s., Ph.D.}

The two Siamese Amathusido were collected by Mr. Godfrey of Bangkok, who has presented the Stichophthalma to the British Museun.

\section{RHOPALOCERA.}

Stichouhthalma godfreyi, sp. n. Hew.

o. This very distinct species is nearest to St. cambodia,

Upper surfuce.-Head brownish rufous; antennæ rufous ; thorax and abdomen greyish brown, abdomen washed with blackish. Fore wing: basal halt greenish steel-blue washed with olive-brown on costal area and from the base distad; onter half greenish white or white tinged with Nile-green; terminal band, apex, and submarginal row of large excised patches black-brown washed with steel-blue; a post.nedian band of dark greenish steel-blue cherrons joined into a chainlike band. Hind wing similar, only the submarginal band of excised patches is replaced by a second row of chevrons and the white ground of the outer half of the wing is 